\title{
PENGELOLAAN KEUANGAN DESA DALAM PERSPEKTIF HAK ASASI MANUSIA: STUDI TERHADAP PENGELOLAAN KEUANGAN DESA DI DESA SEI BAHARU, KECAMATAN HAMPARAN PERAK, KABUPATEN DELI SERDANG, PROVINSI SUMATERA UTARA
}

(Village Financial Management In Human Rights Perspective: a Study on Village Financial Management In Sei Baharu Village, Hamparan Perak District, Deli Serdang Regency, the Province of North Sumatra)

\author{
Donny Michael \\ Pusat Penelitian dan Pengembangan HAM \\ Badan Penelitian dan Pengembangan Hukum dan HAM \\ Kementerian Hukum dan Hak Asasi Manusia Republik Indonesia \\ Jl. HR. Rasuna Said Kav.4-5, Kuningan Jakarta Selatan 12940 \\ Email: dmsitumorang@yahoo.com
}

Tulisan Diterima: 19-05-2017; Direvisi: 17-07-2017; Disetujui Diterbitkan: 09-11-2017

\begin{abstract}
The village is a unit of legal community with territorial boundaries and powers to administer and manage its own administration, the interests of local people based on community initiatives, origins rights, and / or traditional rights recognized and respected within the administration system of the Unitary State of the Republic of Indonesia. The implementation of village administration tasks within the framework of providing services to the community, community empowerment, and management of village development, requires adequate budgetary support. The village government will not be able to finance the village development programs adjusted to the essence of the local issues and priorities of the villagers' needs, as the management of development programs does not rely only on community participation, but also other resources not available in the village that must be financed by the village budget. The formulation of the issues in this research is the extent of the authority of the village administration in managing its financial affairs based on the Human Rights, as well as the mechanism for involving the community (participation) in the management of village finances. The analysis used is qualitative analysis based on qualitative data. The findings on village financial management practices, in particular in Sei Baharu Village, Hamparan Perak District, Deli Serdang Regency, show that the absolute authority and the availability of human resources with adequate capacity and capability have not been ideally described. To that end, the village programs planning should involve all of the community elements, such as, among others: traditional leaders; religious leaders; public figure; educational figure; representatives of farmer groups; fishermen groups; craftsmen groups; women's groups; and the poor, in addition, it is also necessary to set up village-owned enterprises (BUMDesa).
\end{abstract}

Keywords: Financial Management, Human Rights, Village

\begin{abstract}
ABSTRAK
Desa merupakan kesatuan masyarakat hukum yang memiliki batas wilayah yang berwenang untuk mengatur dan mengurus urusan pemerintahan, kepentingan masyarakat setempat berdasarkan prakarsa masyarakat, hak asal usul, dan/atau hak tradisional yang diakui dan dihormati dalam sistem pemerintahan Negara Kesatuan Republik Indonesia. Penyelenggaraan tugas-tugas pemerintahan desa dalam rangka pemberian pelayanan kepada masyarakat, pemberdayaan masyarakat, dan pengelolaan pembangunan desa, memerlukan dukungan anggaran yang memadai agar tugas pemerintahan dapat dilaksanakan. Pemerintah desa tidak akan mampu membiayai program-program pembangunan desa sesuai dengan esensi masalah dan prioritas kebutuhan masyarakat desa, karena pengelolaan program-program pembangunan tidak hanya mengandalkan partisipasi masyarakat, namun juga membutuhkan sumber daya lainnya yang tidak tersedia di desa yang harus dibiayai dari anggaran Pemerintahan Desa. Adapun rumusan masalah dalam penelitian ini adalah sejauhmana kewenangan Pemerintahan Desa dalam pengelolaan keuangan yang berbasis hak asasi manusia, serta bagaimana mekanisme perlibatan masyarakat (partisipasi) dalam pengelolaan keuangan desa. Analisis yang digunakan adalah analisis
\end{abstract}




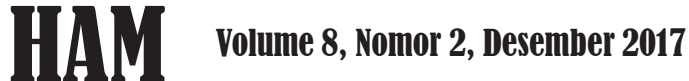

kualitatif yang berbasis pada data-data kualitatif. Dari temuan lapangan ditemukan dalam praktek pengelolaan keuangan desa, khususnya di Desa Sei Baharu, Kecamatan Hamparan Perak, Kabupaten Deli Serdang, antara kewenangan mutlak serta ketersediaan SDM yang memiliki kapasitas dan kapabilitas tidak terdeskripsikan secara ideal. Untuk itu, dalam menyelenggarakan perencanaan program desa perlu diikutsertakan dari unsur masyarakat, misalnya antara lain: tokoh adat; tokoh agama; tokoh masyarakat; tokoh pendidikan; perwakilan kelompok tani; kelompok nelayan; kelompok perajin; kelompok perempuan; dan kelompok masyarakat miskin, selain itu juga perlu dibentuk Badan Usaha Milik Desa (BUMDesa).

Kata Kunci: Pengelolaan Keuangan, Hak Asasi Manusia, Desa

\section{PENDAHULUAN}

\section{Latar Belakang}

Desa dalam pengertian umum sebagai suatu komunitas kecil, yang terikat pada lokalitas tertentu baik sebagai tempat tinggal (secara menetap) maupun bagi pemenuhan kebutuhannya, dan yang terutama yang tergantung pada sektor pertanian. Dalam Penjelasan Pasal 18 Undang-Undang Dasar Negara Republik Indonesia Tahun 1945 (sebelum perubahan) menyebutkan bahwa "dalam teritori Negara Kesatuan Republik Indonesia terdapat \pm 250 "Zelfbesturende landschappen" dan "Volksgemeenschappen", seperti desa di Jawa dan Bali, Nagari di Minangkabau, dusun dan marga di Palembang, dan lain sebagainya.

Dalam perjalanan sistem ketatanegaraan Negara Kesatuan Republik Indonesia, desa telah berkembang dalam berbagai bentuk sehingga perlu dilindungi dan diberdayakan agar menjadi kuat, maju, mandiri, dan demokratis sehingga dapat menciptakan landasan yang kuat dalam melaksanakan pemerintahan dan pembangunan menuju masyarakat yang adil, makmur, dan sejahtera. Definisi Desa menurut Pasal 1 angka 1 UU No.6 Tahun 2014 tentang Desa (selanjutnya UU Desa) adalah sebagai berikut :

Desa adalah desa dan desa adat atau yang disebut dengan nama lain, selanjutnya disebut Desa, adalah kesatuan masyarakat hukum yang memiliki batas wilayah yang berwenang untuk mengatur dan mengurus urusan pemerintahan, kepentingan masyarakat setempat berdasarkan prakarsa masyarakat, hak asal usul, dan/atau hak tradisional yang diakui dan dihormati dalam sistem pemerintahan Negara Kesatuan Republik Indonesia.
Sebagai bagian dari Negara Kesatuan Republik Indonesia dan diakui keberadaannya, secara umum, desa memiliki kewenangan sebagai berikut :

1. Urusan-urusan pelayanan dan pembangunan yang harus disepakati dengan Pemda Kabupaten/Kota :

1.1. Urusan yang lahir karena hak dan kewajiban asal-usul dan/atau prakarsa masyarakat setempat, dan

1.2. Urusan-urusan pemerintahan yang telah disepakati antara masyarakat desa dengan pemerintah daerah untuk dijadikan urusan desa. Karena penyelenggaraan desa bukanlah suatu pemerintahan, maka setelah disepakati oleh kedua belah pihak, kedua urusan di atas tidak lagi disebut sebagai "urusan pemerintahan", melainkan akan disebut sebagai "urusan desa".

2. Urusan yang tidak harus mendapat kesepakatan dengan Pemda Kabupaten/Kota:

2.1. Urusan-urusan yang lahir dari tugas pembantuan dan kewenangan atributif yang lahir karena peraturan perundangundangan (tingkat pusat/provinsi), dan

2.2. Urusan penegakan hukum untuk masyarakat hukum adat tertentu yang harus mendapat kesepakatan dengan lembaga peradilan yang diwakili oleh ketua pengadilan negeri setempat dengan mandat Ketua Mahkamah Agung dan juga kesepakatan dengan pihak kepolisian yang diwakili oleh kepala kepolisian resor dengan mandat dari kepala Kepolisian Republik Indonesia 
untuk bekerjasama sebagai upaya yang mirip dengan Alternative Dispute Resolution (Pilihan Penyelesaian Sengketa). ${ }^{1}$

Untuk menjalankan urusan pemerintahan yang menjadi kewenangannya, desa harus mempunyai sumber keuangan agar mampu memberikan pelayanan dan kesejahteraan kepada rakyat di desanya. Penyelenggaraan tugas-tugas pemerintahan desa dalam rangka pemberian pelayanan kepada masyarakat, pemberdayaan masyarakat, dan pengelolaan pembangunan desa, memerlukan dukungan anggaran yang memadai agar tugas pemerintahan dapat dilaksanakan. Pemerintah desa tidak akan mampu membiayai program-program pembangunan desa sesuai dengan esensi masalah dan prioritas kebutuhan masyarakat desa, karena pengelolaan programprogram pembangunan tidak hanya mengandalkan partisipasi masyarakat, namun juga membutuhkan sumber daya lainnya yang tidak tersedia di desa yang harus dibiayai dari anggaran Pemerintahan Desa.

Ryaas membagi fungsi pemerintahan menjadi empat bagian, yaitu pelayanan (public service), pembangunan (development), pemberdayaan (empowering), dan pengaturan (regulation). ${ }^{2}$ Pelayanan ditujukan kepada upaya pemenuhan hak-hak warga desa, baik hak-hak individu yang mendasar, seperti: hak atas identitas, hak atas kesehatan dan hak pendidikan. Pemberdayaan masyarakat ditujukan kepada peningkatan kemampuan dan kemandirian masyarakat, agar dapat membangun diri dan lingkungannya secara mandiri (dengan tetap mendapat fasilitasi dari pemerintah). Sedangkan pembangunan ditujukan kepada penyediaan berbagai sarana dan prasarana publik guna kepentingan masyarakat desa. Dengan demikian keuangan desasangat penting peranannya dalam membiayai tugas-tugas pemerintahan desa.

Pengertian keuangan desa menurut Pasal 71 UU Desa, bahwa "keuangan desa adalah semua hak dan kewajiban desa yang dapat dinilai dengan uang, serta segala sesuatu baik berupa uang maupun berupa barang yang berhubungan dengan pelaksanaan hak dan kewajiban desa". Atas dasar pengertian tersebut maka hak dan kewajiban desa sangat erat kaitannya dengan penyelenggaraan tugas pemerintahan desa, terutama hak dan kewajiban dalam pengelolaan keuangan desa. Pengelolaan keuangan desa adalah rangkaian seluruh kegiatan dalam rangka mengelola pendapatan dan belanja desa secara efektif dan efisien.

Digunakannya pendekatan hak asasi manusia (HAM) dalam pengelolaan keuangan desa yang menunjang tugas pemerintahan desa dalam rangka membangun sebuah komitmen penghormatan dan pemajuan HAM. Artinya bahwa pendekatan HAM digunakan sebagai prinsip umum serta tindakan yang khusus dalam melaksanakan aturan hukum. Sebagaimana yang telah disampaikan pada paragraf sebelumnya bahwa salah satu tugas pemerintahan desa, pelayanan (services) adalah ditujukan kepada upaya pemenuhan hak-hak warga desa. Dengan demikian, pengelolaan keuangan desa berbasis HAM adalah sebuah keniscayaan.

Pengelolaan keuangan desa merupakan praktek penganggaran yang berkomitmen kepada penghormatan dan pemajuan hak-hak dasar manusia seperti: aksesibilitas serta ketersediaan terhadap pendidikan, kesehatan dan pangan. Pemberdayaan (empowerment) menjadi salah satu alat ukur pengelolaan anggaran berbasis HAM. Di satu sisi, pemberdayaan sangat identik dengan adanya partisipasi publik dalam pengelolaan keuangan desa. Melibatkan masyarakat desa dalam pengelolaan keuangan desa berarti mendudukan posisi mereka sebagai "yang menentukan" (necessary condition), terutama dalam pembangunan desa. Di sisi lain pemberdayaan lebih ditujukan kepada peningkatan kapasitas, dalam hal ini kapasitas pengelolaan keuangan desa, yang menjadi tanggung jawab pemerintah daerah dalam bentuk pembinaan dan pendampingan.

Jumlah desa pada tahun 2016, sesuai Permendagri Nomor 39 Tahun 2015 sebanyak 74.093 desa. Dana Desa akan disalurkan dalam dua tahap periode, yakni pada bulan Maret dan Agustus. Penyaluran dua tahap tersebut dilakukan sesuai dengan diterbitkannya Peraturan Menteri Keuangan (PMK) Nomor 49/PMK.07/2016

1. Mohammad Novrizal Bahar, (2010), Penyempurnaan Pemahaman Tentang Desa : Koreksi Terhadap Pengaturan Desa di Indonesia, Jurnal Konstitusi Pusat Studi Hukum Tata Negara Universitas Indonesia, Volume I Nomor 1. hlm 62-63.

2. Ryaas Rasyid dalam Muhadam Labolo, Memahami Ilmu Pemerintahan Suatu Kajian, Teori, Konsep, dan Pengembangannya. (Jakarta: Rajawali Pers.2010)hlm. 32 
Tentang Tata Cara Pengalokasian, Penyaluran, Penggunaan, Pemantauan, dan Evaluasi Dana Desa. Payung hukum tersebut merupakan turunan dari Peraturan Pemerintah (PP) Nomor 8 Tahun 2016 tentang Perubahan Kedua atas PP Nomor 60 Tahun 2014 tentang Dana Desa yang Bersumber dari Anggaran Pendapatan dan Belanja Negara (APBN).

Berdasarkan Pasal 14 Peraturan Kementerian Keuangan (PMK) 247/2015, Pemerintah akan mencairkan dana desa yang bersumber dari APBN Tahun 2016. Pencarian dana desa akan dilakukan tiga tahap; 40 persen di minggu kedua bulan April, 40 persen di Agustus dan 20 persen di bulan Oktober. ${ }^{3}$ Dana desa tahap I baru disalurkan ke 383 kabupaten/kota dari total 434 kabupaten/kota yang tercatat untuk mendapatkan dana desa. Dana yang telah tersalurkan sebesar Rp 25,2 triliun dari total dana desa tahun 2016 sebesar Rp 46,9 triliun. ${ }^{4}$ Selain Dana Desa, sesuai UU Desa pasal 72, Desa memiliki Pendapatan Asli Desa dan Pendapatan Transfer berupa Alokasi Dana Desa; Bagian dari Hasil Pajak dan Retribusi Kabupaten/ Kota; dan Bantuan Keuangan dari APBD Provinsi/ Kabupaten/Kota. ${ }^{5}$

Sebagai catatan bahwa, pada Tahun 2016 Provinsi Sumatera Utara mendapat dana desa sebesar Rp.3.293 Miliar. Dana tersebut meningkat dari tahun 2015 yang hanya mendapat sebesar Rp.1.460 Miliar. Alokasi anggaran tersebut diperuntukan untuk 5.418 desa yang tersebar di 27 kabupaten di Sumatera Utara. Dari 27 kabupaten tersebut, terdapat lima kabupaten yang mendapatkan dana terbesar dari kabupaten lainnya. Kelima kabupaten tersebut adalah Kabupaten Nias Selatan dengan alokasi dana Rp.272.337.292.000 untuk 459 desa, selanjutnya Kabupaten Deli Serdang dengan alokasi dana senilai Rp.237.763.644.000 untuk 380 desa, lalu Kabupaten Simalungun senilai Rp.230.404.778.000 untuk 386 desa, Kabupaten Padang Lawas Utara mendapatkan alokasi dana Rp.225.561.557.000 untuk 387 desa, dan Kabupaten Mandailing Natal mendapat alokasi dana senilai Rp.222.908.920.000 untuk 377 desa. ${ }^{6}$
Dalam konteks penyelenggaraan tugastugas pemerintahan desa, yang salah satunya adalah pemberian pelayanan kepada masyarakat, pemberdayaan masyarakat, dan pengelolaan pembangunan desa, memerlukan dukungan anggaran yang memadai, pemerintah desa tidak akan mampu membiayai program-program pembangunan desa sesuai esensi masalah dan prioritas kebutuhan masyarakat desa, karena pengelolaan program-program pembangunan desa tidak hanya mengandalkan partisipasi masyarakat, namun juga membutuhkan sumber daya lainnya yang tidak tersedia di desa yang harus dibiayai dari anggaran Pemerintahan Desa.

Bila dicermati secara seksama mengenai pendapatan asli desa pada desa-desa di Indonesia, ternyata sebagian desa-desa di Indonesia memiliki pendapatan asli desa yang sangat rendah (bahkan pada sejumlah desa hampir-hampir tidak memiliki sumber pendapatan asli desa), sehingga rata-rata kemampuan keuangan desa di Indonesia masih sangat rendah. Atas dasar tersebut dianggap penting untuk melakukan Penelitian Pendekatan Hak Asasi Manusia dalam Pengelolaan Keuangan Desa.

Fokus permasalahan yang diangkat adalah sejauhmana kewenangan Pemerintahan Desa dalam pengelolaan keuangan yang berbasis hak asasi manusia? Adapun tujuan penelitian ini adalah untuk mengetahui pengelolaan keuangan yang berbasis hak asasi manusia khususnya pada Pemerintahan Desa Sei Baharu.

\section{METODE PENELITIAN}

Tulisan ini merupakan ringkasan hasil penelitian kerjasama Badan Penelitian dan Pengembangan Hak Asasi Manusia Kementerian Hukum dan HAM RI dengan Badan Penelitian dan Pengembangan Daerah Provinsi Sumatera Utara pada tahun 2016. Penelitian ini merupakan penelitian hukum hak asasi manusia dengan menggunakan pendekatan konseptual (conceptual approach). Jenis penelitian ini merupakan penelitian hukum normatif. Dalam penelitian

3. Diakses dari website: https://www.merdeka.com/peristiwa/pencarian-dana-desa-2o16-dibagi-dalam-tiga-tahap.html

4. Diakses dari website: http://www.beritasatu.com/nasional/370469-penyaluran-dana-desa-2o16-tersendat-kemdes-terjunkan-tim-jdn. html

5. Deputi BidangPengawasan Penyelenggaraan Keuangan Daerah, "Petunjuk Pelaksanaan Bimbingan \& Konsultasi pengelolaan Keuangan Desa", 2015: hlm 1

6. Diakses dari website: http://medan.tribunnews.com/2016/o3/o3/sumut-dapat-peningkatan-dana-desa-sebesar-200-persen 
hukum normatif, sumber data yang utama adalah berupa sumber data sekunder. Analisis yang digunakan adalah analisis kualitatif yang berbasis pada data-data kualitatif.

\section{KERANGKA KONSEPTUAL}

\section{Substansi dalam Pengaturan tentang Desa}

Pokok-pokok di dalam Undang-undang Nomor 6 Tahun 2014 tentang Desa meliputi lima pokok pikiran, yaitu; pertama, tentang apresiasi terhadap pluralitas desa yang ada di Indonesia di dalam undang-undang ini, dimana dalam undang-undang ini mengakui adanya bentuk desa dan desa adat. Kedua, kedudukan desa dan kewenangan desa yang jelas diatur sebagai bagian dari negara kesatuan republik Indonesia. Artinya desa tidak lagi serta merta didefinisikan sebagai bagian integral pemerintahan kabupaten, akan tetapi desa memiliki pengelolaan kekuasaan serta sumber daya yang mandiri sesuai dengan koridor penyelenggaraan pemerintahan demokratis dan konstitusional. Ketiga, konsekuensi pengakuan negara atas desa, yang ditandai dengan distribusi sumber daya keuangan dan ekonomi desa berasal dari anggaran pendapatan dan belanja negara (APBN). Selama ni proyek ke wilayah desa dikendalikan oleh pemerintah provinsi/kabupaten dan juga kementerian. Keempat, demokrasi lebih diperkuat dengan adanya peran badan perwakilan desa (BPD) yang berperan sebagai lembaga pengawasan, budgeting, dan legislasi desa. Selain sebagai mitra kepala desa dan perangkat desa, BPD juga menjadi penyeimbang, khususnya dalam hal yang strategis, seperti; investasi kerjasama antar desa, pengelolaan sumber daya strategis, serta pengambilan keputusan desa yang melibatkan perwakilan masyarakat melalui forum masyarakat desa. Dan yang kelima adalah bahwa desa dengan segala entitasnya harus menjadi subjek dalam pembangunan desa. Dengan demikian program pembangunan yang berhubungan dengan desa wajib menyesuaikan dengan rencana pembangunan jangka menengah desa (RPJMDesa), sebagai bentuk penataan kebijakan pembangunan serta kemandirian desa.
2. Asas Pengelolaan Keuangan Desa

Pengelolaan keuangan desa sangat terikat dengan asas-asas yang relevansinya sangat dekat dengan good governance dan HAM, yaitu: partisipatif, akuntabel, transparan, taat hukum, dan manfaat (patrakumat). Masing-masing memiliki pengertian sebagai berikut; partisipatif dimaksud adalah bahwa pengelolaan keuangan desa wajib melibatkan masyarakat desa, baik dalam tahap perencanaan, pelaksanaan serta evaluasi pelaksanaan keuangan desa. Kemudian akuntabel merupakan bentuk perwujudan dari pertanggungjawabanpengelolaandanpengendalian keuangan desa dalam rangka pencapaian tujuan yang telah ditetapkan. Transparan adalah prinsip keterbukaan yang memungkinkan masyarakat desa mengetahui dan mendapatkan kemudahan akses informasi seluas-luasnya tentang keuangan desa. Taat hukum lebih menekankan kepada pengelolaan keuangan desa wajib berpedoman kepada peraturan perundang-undangan. Asas yang terakhir adalah manfaat, yaitu bahwa pengelolaan keuangan desa diutamakan untuk pemenuhan kebutuhan masyarakat desa (dalam jangka pendek) dan pemenuhan hak-hak dasar masyarakat desa (dalam jangka panjang).

3. Pemerintahan Sebagai Konsep Analitis di dalam Relevansi Good Governance dan HAM

Pada intinya tata pemerintahan tidak selalau identik dengan urusan demokrasi semata. Tata pemerintahan yang baik dapat digambarkan sebagai hubungan yang signifikan, dimana semakin akuntabel suatu pemerintahan terhadap penduduknya, maka semakin besar kemungkinan pemerintahan ini akan menghormati hak-hak warganegaranya. Tata pemerintahan terikat dengan empat sifat yang penting dalam iklim pemerintahan yang sehat, yaitu; otoritas (kewenangan), hubungan timbal balik, kepercayaan dan akuntabilitas? Keempat variabel tersebut saling terkait, dan keempat-empatnya harus dapat dilaksanakan. Semakin banyak empat variabel ini dilaksanakan, maka semakin besar kemungkinan terciptanya good governance, dengan kata lain semakin tinggi pula kemungkinannya hak-hak individu akan dihormati oleh pemerintahan.

7. Hyden, Goran, Governance and the Study of Politics, dalam Michael Bratton dan Goran Hyden (ed.), Governance and politics in Africa, Boulder, Rienner, 1992, hal.102. 
Good governance pada dasarnya adalah suatu konsep yang mengacu kepada proses pencapaian keputusan dan pelaksanaannya yang dapat dipertanggungjawabkan secara bersama. Human interest adalah faktor terkuat yang mempengaruhi baik buruknya dan tercapai atau tidaknya pemerintahan yang baik. Baikburuknya pemerintahan bisa dinilai bila telah bersinggungan dengan semua unsur prinsipprinsip good governance, antara lain yaitu: partisipasi masyarakat, tegaknya supremasi hukum, transparansi, peduli kepada stakeholder, berorientasi kepada konsensus, dan kesetaraan (non-diskriminasi).
Ketiga konsep di atas, baik substansi pengaturan desa, asas pengelolaan keuangan desa, maupun aspek pemerintahan sebagai konsep analitis (relevansi antara good governance dengan HAM), merupakan basis pemikiran dalam melakukan penelitian ini. Asas pengelolaan keuangan sangat berpengaruh terhadap pokokpokok pikiran pikiran yang ada di dalam substansi pengaturan desa dan berpengaruh pula terhadap inti tata pemerintahan. Irisannya terletak pada akuntabilitas, kepercayaan (trust) dan transparansi.

Alur Pikir
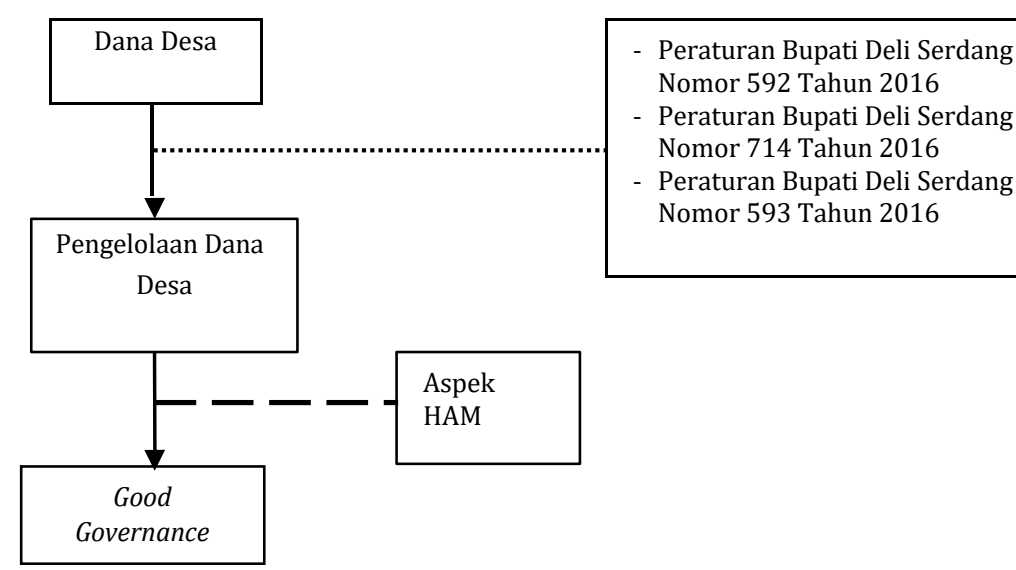

\section{PEMBAHASAN}

Dalam menjalankan roda pemerintahannya, Desa Sei Baharu memiliki panduan peraturan perundang-undangan berupa: Peraturan Bupati Deli Serdang Nomor 592 Tahun 2016 tentang Pengelolaan Keuangan Desa, Peraturan Bupati Deli Serdang Nomor 714 Tahun 2016 tentang Tata Cara Pembagian, Penetapan Perincian dan Pedoman Teknis Penggunaan Dana Desa di Kabupaten Deli Serdang Tahun Anggaran 2016, Peraturan Bupati Deli Serdang Nomor 593 Tahun 2016 tentang Alokasi Dana Desa (ADD) dan Bagian Dari Hasil Pajak Daerah dan Retribusi Daerah, Peraturan Bupati Deli Serdang Nomor 721 Tahun 2016 tentang Kewenangan Lokal Berskala Desa, Peraturan Bupati Deli Serdang Nomor 677 Tahun 2015 tentang Tata Cara Pengadaan Barang/Jasa di Desa, Keputusan Bupati Deli Serdang Nomor 591 Tahun 2016 tentang Besaran Alokasi Dana Desa (ADD) dan Bagian Hasil Pajak Daerah dan
Retribusi Daerah Yang Diterima Oleh Setiap Desa Se-Kabupaten deli Serdang Tahun 2016.

Dalam pengelolaan dana desa, acuan yang menjadi patokan kepala desa Sei Baharu adalah Peraturan Bupati Deli Serdang Nomor 592 Tahun 2016 tentang Pengelolaan Keuangan Desa. Di dalam Bab II Pasal 2 Peraturan Bupati Deli Serdang Nomor 592 Tahun 2016 tentang Pengelolaan keuangan Desa, bahwa Asas Pengelolaan Keuangan Desa dikelola berdasarkan asas-asas transparan, akuntabel, partisipatif serta dilakukan dengan tertib dan disiplin anggaran. Dalam Pasal 6 Peraturan tersebut juga menyebutkan bahwa Kepala Desa sebagai pemegang kekuasaan pengelolaan keuangan desa dan mewakili Pemerintah Desa dalam kepemilikan kekayaan milik desa yang dipisahkan, mempunyai kewenangan sebagai berikut: a) menetapkan kebijakan tentang pelaksanaan APBDesa; b) Menetapkan Pelaksana Teknis Pengelolaan Keuangan Desa (PTPKD); c) Menetapkan Tim 
Pengelola Kegiatan (TPK); d) Menetapkan petugas yang melakukan pemungutan penerimaan desa; e) Menyetujui pengeluaran atas kegiatan yang ditetapkan dalam APBDesa; dan f) Melakukan tindakan yang mengakibatkan pengeluaran atas beban APBDesa. Dalam melaksanakan tugasnya dalam mengelola keuangan desa, kepala desa dibantu oleh PTPKD. Dalam Pasal 3 Peraturan Bupati Deli Serdang Nomor 592 Tahun 2016 tentang Pengelolaan Keuangan Desa, dinyatakan bahwa Tim Pengelolaan Keuangan Desa adalah tim yang dibentuk di tingkat Kabupaten, Tingkat Kecamatan, dan Tingkat Desa, dimana Tim Pembinaan Pengelolaan Keuangan Desa berkedudukan di tingkat Kabupaten, Tim Fasilitasi Pengelolaan Keuangan Desa berkedudukan di tingkat Kecamatan, dan Pelaksana Teknis Pengelolaan Keuangan Desa (PTPKD) berkedudukan di tingkat desa.

Hasil wawancara dengan salah satu pejabat pemerintahan desa di Desa Sei Baharu menyatakan bahwa perencanaan keuangan masih belum tertata dengan baik, terutama perencanaan pengelolaan keuangan untuk kelompok rentan (perempuan dan anak). Pada era pemerintahan SBY sudah ada "Simpan Pinjam Kelompok Perempuan", dimana kegiatan yang dilakukan oleh kaum perempuan dengan aktifitas/kegiatan pengelolaan dana simpanan dan pengelolaan dana pinjaman. Sampai sekarang "Simpan Pinjam Kelompok Perempuan" masih dikelola oleh PNPM, tetapi dalam konteks desa sampai saat ini belum berjalan dengan baik meskipun kelompok "Simpan Pinjam Kelompok Perempuan" itu sudah ada. Hal ini dikarenakan sumber daya manusia yang belum memadai. Selain itu juga, menurut beliau bahwa kaitannya dengan sumber daya manusia, di desa Sei Baharu masih kurang sosialisasi dari pemerintah pusat maupun daerah terkait dengan hak asasi manusia, terumama terkait dengan hak perempuan dan anak-anak

Pada Tahun 2015, pemanfaatan pengelolaan keuangan di Desa Sei Baharu hanya pada tataran infrastuktur desa saja, misalnya perbaikan jalan, hal ini dikarenakan dana desa (keuangan desa) yang diterima oleh Desa Sei Baharu hanya bisa dimanfaatkan untuk perbaikan fasilitas jalan yang digunakan untuk mengangkut sumber daya alam (hasil panen masyarakat). Menurut keterangan dari salah satu informan, ${ }^{8}$ bahwa pemanfaatan dana desa tersebut hasil dari kesepakatan rapat dari pemerintah desa dengan masyarakat. Pada tahun 2015 , dalam perencanaan pemanfaatan dana desa 2015, pemerintah desa mengundang tokoh agama, tokoh masyarakat, BPD, LKMD, kelompoknelayan untuk merencanakan musyawarah desa. Partisipasi masyarakat berkaitan dengan infrastruktur adalah masyarakat bersedia memberikan sebahagian tanahnya untuk pelebaran dan perbaikan jalan umum, dan pemerintah tidak perlu mengganti rugi atas tanah tersebut. Jadi pihak BPD dengan masyarakat membantu penyelenggaraan infrastruktur jalan. Menurut informan, alokasi dana desa untuk akses pendidikan dan kesehatan belum dapat dilaksanakan dikarenakan belum adanya petunjuk yang jelas.

Sama halnya dengan Tahun 2016, rencana realisasi pemanfaatan anggaran (dana desa) akan dialokasikan ke bidang infrasruktur semua, tidak ada anggaran yang dimanfaatkan untuk pemberdayaan sumber daya manusia. hal ini juga dikarenakan dana desa yang diberikan tidak dapat dimanfaatkan oleh kelompok-kelompok masyarakat desa. Salah satu sebabnya adalah keberadaan kelompok-kelompok yang sada masih belum jelas (misalnya: ada namanya kelompoknya tapi keberadaannya/alamatnya tidak jelas), sehingga hal tersebut akan sangat sulit dipertanggungjawabkan. Sampai saat ini (bulan September 2016), dana desa tahap pertama di tahun 2016 belum dapat dimanfaatkan, masih dalam tahap pengkajian di kabupaten. Rencana program desa (RPJMDes) berserta RKP masih dalam tahap perbaikan oleh pendamping desa di Kabupaten.

Dalam hal pendamping desa, pada tahun 2016 hanya ada 1 (satu) orang pendamping yang diberikan kecamatan untuk melakukan pendampingan di 4 (empat) desa termasuk Desa Sei Baharu, hal inilah yang mengakibatkan keterlambatan proses perbaikan RPJMDes dan RKP serta RAB di kabupaten. Selain itu juga, orang tersebut bukan merupakan penduduk desa Sei Baharu, sehingga sangat sulit membagi waktu ke empat (4) desa. Dalam hal perencanaan pembangunan infrastruktur di Tahun 2016, di Desa Sei Baharu belum adanya tenaga ahli tehnik sipil dan tenaga pengadaan barang untuk membuat

8. Wawancara dengan Bendahara Desa Sei Baharu tanggal 23 September 2016 
perencanaan infrastruktur yang baik. Kendala yang lain bahwa di Desa Sei Baharu belum terbentuk BUMDesa, sehingga dana penyertaan modal belum bisa dimanfaatkan. Terlebih lagi, dengan adanya dana desa, seringkali ada Lembaga Swadaya Masyarakat (LSM) yang kemungkinan tidak jelas keberadaannya mencari-cari kesalahan dalam pengelolaan dana desa.

Jika melihat aturan hukum Pemerintah Daerah Kabupaten Deli Serdang, yang mengatur tentang "Tim Pengelolaan Keuangan Desa", maka yang muncullah beberapa asumsi, bahwa: pertama aturan ini memang sengaja dibuat oleh Pemerintah Daerah kabupaten Deli Serdang guna mengantisipasi permasalahan dalam pengelolaan keuangan desa. Namun jika demikian maka, dasar hukum apa yang digunakan oleh Pemerintah Daerah Kabupaten Deli Serdang dalam membentuk "Tim Pengelolaan Keuangan" dan apakah kewenangan pengelolaan keuangan desa oleh pemerintahan desa harus diatur dan merujuk pada pedoman yang dibuat oleh Pemerintah Daerah Kabupaten.

Berbicara tentang keuangan desa, maka perlu dilihat kembali tujuan dari terbentuknya UndangUndang Nomor 6 Tahun 2014 tentang Desa, yaitu:

1. memberikan pengakuan dan penghormatan atas desa yang sudah ada dengan keberagamannya sebelum dan sesudah terbentuknya Negara Kesatuan Republik Indonesia;

2. memberikan kejelasan status dan kepastian hukum atas desa dalam sistem ketatanegaraan Republik Indonesia demi mewujudkan keadilan bagi seluruh rakyat Indonesia;

3. melestarikan dan memajukan adat, tradisi, dan budaya masyarakat desa;

4. mendorong prakarsa, gerakan, dan partisipasi masyarakat desa untuk pengembangan potensi dan aset desa guna kesejahteraan bersama;

5. membentuk pemerintahan desa yang profesional, efisien dan efektif, terbuka, serta bertanggung jawab;

6. meningkatkan pelayanan publik bagi warga masyarakat desa guna mempercepat perwujudan kesejahteraan umum;

7. meningkatkan ketahanan sosial budaya masyarakat desa guna mewujudkan masyarakat desa yang mampu memelihara kesatuan sosial sebagai bagian dari ketahanan nasional;

8. memajukan perekonomian masyarakat desa serta mengatasi kesenjangan pembangunan nasional; dan

9. memperkuat masyarakat desa sebagai subjek pembangunan.

Poin 1, 2, dan 5 jelas menunjukkan bahwa UU Desa diarahkan kepada kemandirian pemerintahan desa, pengakuan dan penghormatan terhadap pemerintahan desa. Ketidaksiapan sumber daya manusia dan infratsruktur pendukung dalam pengelolaan keuangan harus disikapi dengan tindakan alternatif dari Pemerintah Daerah Kabupaten dengan cara, misalnya: menempatkan sebagian tenaga/SDM pengelolaan keuangan yang dimiliki Pemerintahan Kabupaten atau pada tingkat Kecamatan yang diperbantukan pada Pemerintahan Desa dalam rangka membantu pengelolaan keuangan desa, dalam jangka waktu tertentu; atau cara lainnya yang sesuai dengan peraturan perundang-undangan, ketimbang membuat "Tim Pengelolaan Keuangan" yang belum ada dasar hukum yang jelas yang mengatur tentang hal tersebut.

Dalam Pasal 18 ayat (2) dan ayat (5) UUD Tahun 1945 menyatakan bahwa Pemerintahan Daerah berwenang untuk mengatur dan mengurus sendiri Urusan Pemerintahan menurut Asas Otonomi dan Tugas Pembantuan dan kepada daerah diberikan otonomi yang seluas-luasnya. Pemberian otonomi seluas-luasnya kepada Daerah diarahkan untuk mempercepat terwujudnya kesejahteraan masyarakat melalui peningkatan pelayanan, pemberdayaan, dan peran serta masyarakat. Selanjutnya dalam Pasal 18 ayat (7) UUD Tahun 1945 ditentukan bahwa; susunan dan tata cara penyelenggaraan pemerintahan daerah diatur dalam Undang-Undang.

Dalam praktek berkaitan dengan keuangan desa, berlakunya UU Desa, dianggap membawa angin segar bagi desa-desa di Indonesia. Hal ini disebabkan karena adanya tiga (3) keistimewaan dalam UU Desa yakni; pertama, besarnya dana yang mengalir ke Desa (Pasal 72); kedua, penghasilan kepala desa (Pasal 66) dan ketiga, kewenangan Kepala Desa dalam mengelola keuangan desa (Pasal 75). Selain itu juga, dalam Pasal 3 ayat (1) Peraturan Menteri Dalam Negeri Nomor: 113 
tahun 2014 tentang Pengelolaan Keuangan Desa menyatakan bahwa Kepala Desa adalah pemegang kekuasaan pengelolaan keuangan desa dan mewakili Pemerintah Desa dalam kepemilikan kekayaan milik desa yang dipisahkan.

Arti kewenangan dimaksud, yang berkaitan dengan hukum, disebut sebagai wewenang rasional atau legal, yakni wewenang yang berdasarkan suatu sistem hukum dan dipahami sebagai suatu kaidah-kaidah yang telah diakui serta dipatuhi oleh masyarakat dan bahkan yang diperkuat oleh Negara. Di dalam kewenangan terdapat wewenang-wewenang (rechtsbe voegdheden). Wewenang merupakan lingkup tindakan hukum publik, lingkup wewenang pemerintahan, tidak hanya meliputi wewenang membuat keputusan pemerintah (bestuur), tetapi meliputi wewenang dalam rangka pelaksanaan tugas, dan memberikan wewenang serta distribusi wewenang utamanya ditetapkan dalam peraturan perundang-undangan. Namun secara yuridis, pengertian wewenang adalah kemampuan yang diberikan oleh peraturan perundang-undangan untuk menimbulkan akibatakibat hukum. Oleh karenanya kewenangan pengelolaan keuangan desa jelas merupakan wewenang rasional atau legal dari seorang kepala desa yang mewakili pemerintahan desa yang didasarkan pada sistem hukum dan diakui oleh negara melalui Undang-undang Desa.

Dalam kaitannya dengan kewenangan pemerintahan desa, Peraturan Pemerintah Nomor 22 Tahun 2015 sebagai perubahan atas Peraturan Pemerintah Nomor 60 Tahun 2014 tentang Dana Desa Yang Bersumber Dari Anggaran Pendapatan Dan Belanja Negara sebagai petunjuk pelaksanaannya telah menjadi payung hukum buat perangkat desa dalam melakukan pengelolaan dana desa. Namun untuk pengelolaan dana desa bukanlah hal yang mudah, akan tetapi juga memerlukan sistem yang harus dibuat secara profesional. Mulai dari segi perencanaan, maka desa harus membentuk musyawarah desa untuk menentukan belanja bagi dana desa pada periode ke depan. Kemudian penatausahaannya pun harus menggunakan sistem yang telah memanfaatkan teknologi informasi. Tidak hanya sistem saja, sumber daya manusia (SDM) atau perangkat penyelenggara desa pun harus memiliki kapabilitas dalam mengelola dana tersebut. Hal tadi bukan pekerjaan yang mudah dan cepat adalam mempersiapkan SDM desa agar kapabel dan profesional.
Undang-Undang yang ada telah mengatur bahwa mekanisme pengelolaan keuangan desa saat ini mirip dengan mekanisme pengelolaan APBD Provinsi/kabupaten/kota. Demikian juga dengan manajemen asetnya. Akan tetapi cukup banyak fakta menunjukkan bahwa, pengelolaan APBD provinsi/kota/kabupaten yang didukung dengan SDM yang lebih baik dan berpengalaman saja masih sering terjadi penyimpangan, bagaimana dengan Pemerintahan Desa yang kapasitas SDMnya sangat terbatas.

Dengan demikian, antara kewenangan pengelolaan keuangan desa sebagai salah satu bentuk pengakuan pemerintah pusat yang secara substantif menekankan tentang kedaulatan desa, dengan sistem pengelolaan keuangan desa yang harus dibuat secara profesional, maka ketersediaan SDM yang terampil dan profesional sangat mutlak dibutuhkan Pemerintah Desa. Meski terampil dan profesional saja tidak cukup oleh karena pengetahuan dan pemahaman tentang aturan hukum yang berlaku juga sangat dibutuhkan. Sulitnya menjalankan kewenangan mutlak (secara rasional/legal) dalam pengelolaan keuangan desa tanpa didukung oleh ketersediaan SDM yang memiliki kapasitas dan kapabilitas dalam pengelolaan keuangan desa.

Dalam praktek pengelolaan keuangan desa, khususnya di Desa Sei Baharu, Kecamatan Hamparan Perak, Kabupaten Deli Serdang, antara kewenangan mutlak serta ketersediaan SDM yang memiliki kapasitas dan kapabilitas tidak terdeskripsikan secara ideal. Yang Nampak justeru bentuk "kepasrahan" Pemerintahan Desa dalam pengelolaan keuangan desa, oleh karena pemerintahan desa tidak siap melaksanakan apa yang telah diberikan kewenangannya dalam pengelolaan keuangan desa. Dari data yang ada, Desa Sei Baharu belum bisa mengelola aset, potensi yang ada di desa tersebut. Hal ini dapat dilihat dari belum terbentuknya BUMDesa, sedangkan potensi yang ada dapat dibentuk. Misalnya ada kelompok-kelompok masyarakat yang berkeinginan untuk meningkatkan usaha pendapatan masyarakat (perkebunan dan tanaman budidaya enceng gondok). Hal ini juga disebabkan legalitas keberadaan kelompok-kelompok masyarakat yang belum secara merata, bahkan domisilinya masih berpindah-pindah. Hal ini yang menyebabkan pemerintah desa Sei Baharu sulit untuk memberikan dana/anggaran untuk 
pemberdayaan masyarakat tersebut dikarenakan pertanggungjawaban akan keluarnya dana tersebut.

Berkaitan hal tersebut di atas, seharusnya perencanaan desa diawali dengan pendataan aset, potensi dan kekuatan desa. Data tersebut menjadi dasar perencanaan pembangunan enam tahun yang tertuang dalam Rencana Pembangunan Jangka Menengah Desa (RPJMDes) dan Rencana Kegiatan Pembangunan Desa (RKPDes). Keduanya menjadi dokumen resmi dalam rencana pembangunan desa yang dibiayai oleh anggaran pendapatan dan belanja desa (APBDes). Dalam kenyataannya, program-program yang seharusnya sudah dilaksanakan sesuai dengan RPJMDes untuk Tahun 2016 sampai bulan September 2016 belum selesai dibuat masih dalam perbaikan oleh pendamping desa di kabupaten Lubuk Pakam. Atas dasar itulah, program-program kepala desa tidak dapat berjalan dikarenakan tidak ada acuan program. Padahal seharusnya pada bulan September, Desa Sei Baharu sudah menerima dana desa gelombang kedua. Kendala yang lain adalah kurangnya tenaga pendamping desa. Hal ini dapat dilihat bahwa tenaga pendamping yang ada untuk membantu di empat (4) desa termasuk Desa Sei Baharu hanya ada satu (1) orang tenaga pendamping. Padahal menjadi pendamping desa merupakan tugas yang sangat berat. Mengingat desa sebagai tiang pembangunan ekonomi negara maka banyak sekali hal yang harus dikerjakan oleh para pendamping desa selama bertugas di desa yang di dampinginya.

Secara umum pendamping desa bertugas mendampingi desa dalam penyelenggaraan pembangunan desa dan pemberdayaan masyarakat desa. Pendamping desa sendiri dibagi dalam tiga kategori yang terdiri dari tenaga pendamping profesional, kader pemberdayaan masyarakat desa, dan atau pihak ketiga. Tenaga pendamping profesional terdiri atas pendamping Desa (berkedudukan di kecamatan), pendamping teknis (berkedudukan di kabupaten), dan tenaga ahli pemberdayaan masyarakat (berkedudukan di pusat dan provinsi) dengan tugas masing-masing (hal ini sesuai dengan pasal 2 Peraturan Bupati Deli Serdang Nomor 592 Tahun 2016 tentang Pengelolaan Keuangan Desa). Fungsi Pendamping Desa ada 13, yaitu: 1) Fasilitasi penetapan dan pengelolaan kewenangan lokal berskala desa dan kewenangan desa berdasarkan hak asalusul; 2) Fasilitasi penyusunan dan penetapan peraturan desa yang disusun secara partisipatif dan demokratis; 3) Fasilitasi pengembangan kapasitas para pemimpin desa untuk mewujudkan kepemimpinan desa yang visioner, demokratis dan berpihak kepada kepentingan masyarakat desa; 4) Fasilitasi demokratisasi desa; 5) Fasilitasi kaderisasi desa; 6) Fasilitasi pembentukan dan pengembangan lembaga kemasyarakatan desa; 7) Fasilitasi pembentukan dan pengembangan pusat kemasyarakatan (community center) di desa dan/ atau antar desa; 8) Fasilitasi ketahanan masyarakat desa melalui penguatan kewarganegaraan, serta pelatihan dan advokasi hukum; 9) Fasilitasi desa mandiri yang berdaya sebagai subyek pembangunan mulai dari tahap perencanaan, pelaksanaan dan evaluasi pembangunan desa yang dilaksanakan secara partisipatif, transparan dan akuntabel; 10) Fasilitasi kegiatan membangun desa yang dilaksanakan oleh supradesa secara partisipatif, transparan dan akuntabel; 11) Fasilitasi pembentukan dan pemngembangan Badan Usaha Milik Desa (BUM Desa); 12) Fasilitasi kerjasama antar desa dan kerjasama desa dengan pihak ketiga; 13. Fasilitasi pembentukan serta pengembangan jaringan sosial dan kemitraan. Dari tugas dan fungsi pendamping desa dapat dibayangkan bahwa sangat berat jika tugas dan fungsi pendamping hanya dilakukan oleh satupendamping saja, apalagi satu (1) orang pendamping tersebut mengurusi empat (4) desa yang ada di kabupaten/kota Propinsi Sumatera Utara.

Begitu banyaknya permasalahan dalam pembangunan desa maka diperlukan suatu strategi untuk mengatasinya. Strategi dasar yang dilakukan dalam pembuatan kebijakan adalah pembangunan yang diarahkan dengan pelibatan masyarakat dalam pembangunan. Partisipasi masyarakat mempunyai peran yang sangat penting dalam pembangunan karena pembangunan ditujukan untuk memenuhi kebutuhan dari masyarakat itu sendiri dan dengan adanya peran partisipasi masyarakat dalam proses pembangunan diharapkan hasil dari pembangunan sesuai dengan apa yang diharapkan dan dibutuhkan oleh daerah tersebut.

Pasal 82 UU Desa menyatakan secara tegas hak masyarakat untuk mendapatkan informasi dan terlibat aktif mengawasi pelaksanaan pembangunan. Pasal ini juga memuat kewajiban pemerintah desa untuk memberikan informasi rencana pembangunan apa saja yang akan dilaksanakan. Mengacu pasal ini, masyarakat 
desa dapat melakukan pemantauan pelaksanaan pembangunan desa. Berbagai temuan hasil pemantauan, termasuk berbagai keluhan atas pelaksanaan pembangunan desa, dapat disampaikan masyarakat kepada Pemerintah Desa dan Badan Permusyawaratan Desa. Hasil pemantauan dan berbagai keluhan atas pelaksanaan Pembangunan Desa kemudian disampaikan masyarakat kepada Pemerintah Desa dan Badan Permusyawaratan Desa. Masyarakat desa juga dapat memberikan tanggapan atas laporan pelaksanaan pembangunan di desa selama satu tahun itu pada saat Musyawarah Desa.

Jika kita memahami konsideran dan tujuan terbentuknya Undang-Undang Nomor 6 Tahun 2014 tentang Desa maka hal tersebut merupakan wujud penghormatan, perlindungan dan pemenuhan hak asasi manusia, terutama dilihat dari aspek hak-hak sipil dan politik. Hal ini merujuk pada Pasal 1 ayat (1) Kovenan Internasional Hak-hak Sipil dan Politik bahwa "semua bangsa berhak untuk menentukan nasib sendiri". Berdasarkan hak tersebut mereka bebas untuk menentukan status politik mereka dan bebas untuk mengejar kemajuan ekonomi, sosial dan budaya mereka. Dalam Hukum Hak Asasi Manusia, setelah diundangkannya UU Desa yang menetapkan status dan kepastian hukum atas desa dalam sistem ketatanegaraan Republik Indonesia, maka Pemerintahan Desa merupakan representatif dari negara. Oleh karena itu pemerintah desa berkedudukan sebagai pemegang tanggung jawab pelaksanaan hak asasi manusia dan warga masyarakat desa sebagai pemegang hak asasi mnusia.

Anggaran, menjadi salah satu alat indikator respon negara dalam pemenuhan hak-hak rakyat untuk memperoleh akses yang layak secara sosial ekonomi. Dalam soal hak asasi manusia, anggaran menjadi suatu kekuatan tarik menarik antara penguasa dengan kelompok marjinal yang mengharapkan fasilitas kewajiban negara (state obligation) secara khusus dalam hak sosial ekonomi. Sejauhmana negara memajukan hak sosial ekonomi, dapat diukur dan dilihat secara transparan dari indikator kewajiban negara; penghormatan, perlindungan dan pemenuhan hak asasi manusia, yang disesuaikan dengan realitas dukungan sumber daya lokal yang ada. Sehingga, dalam kaitannya dengan pengelolaan keuangan desa yang menunjang pemerintahan desa, maka harus tergambar tentang bagaimana sensifitas dan responsifitas pemerintah desa terhadap kelompok masyarakat yang rentan dalam penikmatan (enjoyment) hak-hak dasarnya, seperti: perempuan hamil, anak-anak, penyandang disabilitas dan lanjut usia. Terlebih lagi kepada mereka yang termasuk dalam kategori masyarakat miskin, hal ini dikarenakan masyarakat miskin sangat rentan terlanggar haknya, terutama dalam mengakses hakhak dasar. Dalam mengedepankan prinsip-prinsip good governance dan HAM dalam pengelolaan keuangan, khususnya di Desa Sei Baharu perlu adanya otoritas (kewenangan), hubungan timbal balik, kepercayaan dan akuntabilitas dalam pengelolaan keuangan.

\section{KESIMPULAN}

Kewenangan pengelolaan keuangan desa sendiri merupakan salah satu bentuk pengakuan Pemerintah Pusat yang secara substantif lebih menekankan kedaulatan desa. Dengan sistem pengelolaan keuangan desa yang harus dibuat secara profesional, maka ketersediaan SDM yang terampil dan profesional sangat mutlak dibutuhkan Pemerintah Desa. Meski terampil dan profesional saja tidak cukup oleh karena pengetahuan dan pemahaman tentang aturan hukum yang berlaku juga sangat dibutuhkan. Sulitnya menjalankan kewenangan mutlak (secara rasional/legal) dalam pengelolaan keuangan desa tanpa didukung oleh ketersediaan SDM yang memiliki kapasitas dan kapabilitas dalam pengelolaan keuangan desa, seperti halnya yang terdapat pada desa Sei Baharu.

Dalam praktek pengelolaan keuangan desa, khususnya di Desa Sei Baharu, Kecamatan Hamparan Perak, Kabupaten Deli Serdang, antara kewenangan mutlak serta ketersediaan SDM yang memiliki kapasitas dan kapabilitas tidak terdeskripsikan secara ideal. Yang Nampak justru bentuk "kepasrahan" Pemerintahan Desa dalam pengelolaan keuangan desa, oleh karena pemerintahan desa tidak siap melaksanakan apa yang telah diberikan kewenangannya dalam pengelolaan keuangan desa.

Dalam pengelolaan keuangan desa sangat terkait erat dengan hak asasi manusia (HAM). Dalam pengelolaan keuangan desa haruslah bersifat partisipatif, akuntabel, transparan, taat hukum, dan manfaat. Hal ini menggambarkan bahwa pengelolaan keuangan desa wajib melibatkan 
masyarakat desa, baik dalam tahap perencanaan, pelaksanaan serta evaluasi pelaksanaan keuangan desa. Selain itu juga adanya pinsip keterbukaan yang memungkinkan masyarakat desa mengetahui dan mendapatkan kemudahan akses informasi seluas-luasnya tentang keuangan desa. Hal lain yang tidak kalah pentingnya adalah pengelolaan keuangan desa diutamakan untuk pemenuhan kebutuhan masyarakat desa (dalam jangka pendek) dan pemenuhan hak-hak dasar masyarakat desa (dalam jangka panjang). Hal inilah yang belum tergambarkan dalam pengelolaan keuangan desa Sei Baharu.

\section{SARAN}

Dari analisa dan kesimpulan di atas, maka penelitian dengan judul Pengelolaan Keuangan Desa Dalam Perspektif Hak Asasi Manusia, perlu merekomendasikan kepada Pemerintah Desa Sei Baharu, Kecamatan Hamparan Perak, Kabupaten Deli Serdang, Provinsi Sumatera Utara bahwa dalam menyelenggarakan perencanaan program desa perlu diikutsertakan dari unsur masyarakat, misalnya antara lain: tokoh adat; tokoh agama; tokoh masyarakat; tokoh pendidikan; perwakilan kelompok tani; kelompok nelayan; kelompok pengrajin; kelompok perempuan; dan kelompok masyarakat miskin; Dalam meningkatkan percepatan program-program desa, perlu ditambahkan sumber daya manusia sebagai pendamping desa dari Kabupaten, atau menciptakan pendamping-pendamping baru yang berasal dari masyarakat desa itu sendiri dengan membuat pelatihan-pelatihan terkait dengan pengelolaan keuangan dan pemberdayaan sumber daya alam dan masyarakat; Serta segera membentuk Badan Usaha Milik Desa (BUMDesa) guna meningkatkan produktifitas masyarakat desa, sehingga dapat menambah pendapatan daerah. 


\section{DAFTAR PUSTAKA}

Buku:

Deputi Bidang Pengawasan Penyelenggaraan Keuangan Daerah, "Petunjuk Pelaksanaan Bimbingan \& Konsultasi pengelolaan Keuangan Desa”, 2015

Hyden, Goran, Governance and the Study of Politics, dalam Michael Bratton dan Goran Hyden (ed.), Governance and politics in Africa, Boulder, Rienner, 1992

Jef Haynes, Third World Politics, A Concise Introduction, London, Blackwell Publishers, 1996

Mohammad Novrizal Bahar, Penyempurnaan Pemahaman Tentang Desa: Koreksi Terhadap Pengaturan Desa di Indonesia, Jurnal Konstitusi Pusat Studi Hukum Tata Negara Universitas Indonesia, Volume I Nomor 1, (2010),

Ryaas Rasyid dalam Muhadam Labolo, Memahami Ilmu Pemerintahan Suatu Kajian, teori, Konsep, dan Pengembangannya. (Jakarta: Rajawali Pers.2010)

\section{Peraturan Perundang-undangan:}

Undang-Undang Nomor 6 Tahun 2014 tentang Desa

Peraturan Pemerintah Nomor 22 Tahun 2015 sebagai perubahan atas Peraturan Pemerintah Nomor 60 Tahun 2014 tentang Dana Desa Yang Bersumber Dari Anggaran Pendapatan Dan Belanja Negara

Peraturan Pemerintah Nomor 8 Tahun 2016 tentang Perubahan Kedua atas PP Nomor 60 Tahun 2014 tentang Dana Desa yang Bersumber dari Anggaran Pendapatan dan Belanja Negara (APBN).

Peraturan Menteri Keuangan (PMK) Nomor 49/PMK.07/2016 Tentang Tata Cara Pengalokasian, Penyaluran, Penggunaan, Pemantauan, dan Evaluasi Dana Desa.

Peraturan Bupati Deli Serdang Nomor 592 Tahun 2016 tentang Pengelolaan keuangan Desa
Peraturan Bupati Deli Serdang Nomor 593 Tahun 2016 tentang Alokasi Dana Desa (ADD) dan Bagian Dari Hasil Pajak Daerah dan Retribusi Daerah

Peraturan Bupati Deli Serdang Nomor 714 Tahun 2016 tentang Tata Cara Pembagian, Penetapan Perincian dan Pedoman Teknis Penggunaan Dana Desa di Kabupaten Deli Serdang Tahun Anggaran 2016,

Peraturan Bupati Deli Serdang Nomor 721 Tahun 2016 tentang Kewenangan Lokal Berskala Desa, Peraturan Bupati Deli Serdang Nomor 677 Tahun 2015 tentang Tata Cara Pengadaan Barang/Jasa di Desa,

Keputusan Bupati Deli Serdang Nomor 591 Tahun 2016 tentang Besaran Alokasi Dana Desa (ADD) dan Bagian Hasil Pajak Daerah dan Retribusi Daerah Yang Diterima Oleh Setiap Desa Se-Kabupaten deli Serdang Tahun 2016.

\section{Website:}

https://www.merdeka.com/peristiwa/pencariandana-desa-2016-dibagi-dalam-tiga-tahap. html

http://www.beritasatu.com/nasional/370469penyaluran-dana-desa-2016-tersendatkemdes-terjunkan-tim-jdn.html

http//medan.tribunnews.com/2016/03/03/sumutdapat-peningkatan-dana-desa-sebesar-200persen 